\title{
Environmental monitoring of Archips podana (fruit tree tortrix moth) in Bramley apple orchards in Northern Ireland
}

\author{
${ }^{1 *}$ A. G. S. Cuthbertson and ${ }^{2}$ A. K. Murchie \\ ${ }^{1}$ Central Science Laboratory, Sand Hutton, York YO41 1LZ, UK \\ ${ }^{2}$ Department of Agriculture and Rural Development for Northern Ireland and the Queen's University of Belfast, \\ Newforge Lane, Belfast BT9 5PX, UK
}

\begin{abstract}
Apple is host to many species of tortricid moths. Archips podana is an economically important species in the Bramley's Seedling apple orchards of Northern Ireland. Chemical pesticides are routinely applied to control moth populations. Pheromone trapping has shown that the moths are not concentrated in any particular habitat. Moth damage to fruit is generally negligible. The need for careful judgement to be applied before deciding on the application of chemical pesticides to control moth populations is discussed.
\end{abstract}

Key words: Archips podana, Anystis baccarum, Bramley apple, chemical pesticides, spray threshold

*Corresponding Author, E-mail: a.cuthbertson@csl.gov.uk

\section{Introduction}

Apple is host to an extensive fauna of tortricid moths (Cross, 1996). Mészáros, et al. (1984) recorded 88 species in the apple orchards of Hungary and at least 25 species have been recorded as pests in apple orchards throughout the United Kingdom (UK) (Alford, 1984). However, most of them have been considered to be of minor importance and out of the vast array of species only three are considered to be significant pests by UK apple growers. These are: (1) Cydia pomonella ((Linnaeus), codling moth); (2) Adoxophyes orana ((Fischer von Röslerstamm), summer fruit tortrix moth); (3) Archips podana ((Scopoli), fruit tree tortrix moth). It is the latter species that occurs significantly in Bramley's Seedling apple orchards in Northern Ireland (Mowat and Clawson, 1996).

Archips podana hibernate as young larvae in cocoons fixed to twigs or buds. These emerge in spring over a fairly long period from late March to early May when leaf buds are at the green cluster or flower buds at the pink bud stage. Pupation occurs in late May to early June inside leaves that have been spun together by the larvae. The adult moths appear during mid-June and are found mostly up until mid-August. The greatest numbers of moths appear in late June or July depending on the climatic conditions. Eggs are laid in several batches of 50100 eggs on the upper surface of leaves during June and July (Bradley, et al., 1973). The egg mass is covered with a wax-like secretion that so closely matches the green colour of the leaf that detection is difficult (Massee, 1954). Hatching of eggs occurs within 17-23 days (Massee, 1946). Larvae disperse after hatching and, whilst young, each one lives in a silken web placed beside the midrib on the underside of a leaf. This new generation larvae may cause further damage to the apple fruit before they hibernate. Larvae taken into apple stores can even continue to feed on the fruit. Some of the larvae of the new generation hibernate after moulting once or twice; others develop to maturity and give rise to a second generation of moths in September and early October. Numbers of $A$. podana have been found to regularly exceed the recommended UK Agricultural Development and Advisory Service (ADAS) action threshold of 30 moths per pheromone-baited trap per week (Cross and Berrie, 1994) in Northern Irish commercial Bramley's Seedling apple orchards (Mowat and Clawson, 1996). However, despite greatly exceeding the spray threshold for treatment, rarely any of the apples are considered unmarketable; although some may be downgraded, overall damage is generally negligible (Mowat and Clawson, 1996). The aim of this study was to monitor $A$. podana numbers in managed orchards (insecticides applied) compared with unmanaged habitats (surrounding habitats with no insecticides applied), and to test if the pheromone traps were simply attracting the moths into the Bramley orchards from the surrounding habitats. 
The study was carried out at the Northern Ireland Horticulture and Plant Breeding Station in Loughgall, County Armagh, Northern Ireland, United Kingdom. During 1997.

\section{Materials and Methods}

Archips podana were monitored using pheromone traps made out of $1.75 \mathrm{l}$. milk cartons. The inside of each was coated with Hyvis glue (British Petroleum, Belfast, UK) and contained a female sex pheromone dispenser (cis-11-and trans11-tetradecenyl acetate, 1:1 ratio) (van der Kraan and van Deventer, 1982) (Agralan Limited, Swindon, UK). Five traps were placed in managed orchards and five in unmanaged habitats (Table 1). Numbers of $A$. podana caught were recorded weekly from 20 June until 28 October 1997. Fresh pheromone dispensers were put in the traps after 6 weeks. The habitats were all situated within a five mile radius of the Northern Ireland Horticultural and Plant Breeding Station, Loughgall, County Armagh, UK (N 054 24.3' W 006 35.8').
To assess the female $A$. podana population and compare trapping efficiencies, two additional sampling methods were employed in the managed orchards. A $12 \mathrm{~V}$ heath portable moth light trap was placed in between the rows of trees at a height of 1 $\mathrm{m}$. above the ground from $22.00 \mathrm{~h}$. until $03.00 \mathrm{~h}$. (GMT) on four nights (23-24 June and again on 1819 July). On the same nights, the lower branches of 20 trees were sweep netted (15 sweeps each) under spotlight at 24.00 h. (GMT). Data underwent analysis of variance using ANOVA.

\section{Results}

No significant difference was obtained between numbers of $A$. podana in managed orchards compared to unmanaged habitats (Figure 1) during peak time of occurrence on 11 July $(\mathrm{F}=1.11 ; \mathrm{df}=$ $1,9 ; \mathrm{P}=0.35)$, or 18 July $(\mathrm{F}=6.47 ; \mathrm{df}=1,9 ; \mathrm{P}=$ 0.06). Managed orchards had a peak mean of 72 moths caught per trap per week compared to 63 for unmanaged habitats.

Table 1: Unmanaged habitats in which pheromone traps were placed to sample for Archips podana

\begin{tabular}{|llc|}
\hline \multicolumn{1}{|c}{ Site } & \multicolumn{1}{c|}{ Dominant vegetation } & Distance to apple trees (m.) \\
\hline $\begin{array}{l}\text { Windbreak surrounding managed } \\
\text { orchard }\end{array}$ & Poplar (Populus sp.) & 10 \\
$\begin{array}{l}\text { Windbreak surrounding unmanaged } \\
\text { orchard }\end{array}$ & Hawthorn (Crataegus monogyna) & 10 \\
$\begin{array}{l}\text { Eight abandoned apple trees } \\
\text { surrounded by coniferous forest }\end{array}$ & $\begin{array}{l}\text { Norway spruce Picea abies, Scots } \\
\text { pine (Pinus sylvestris) } \\
\text { Agroforestry site }\end{array}$ & Ash (Fraxinus excelsior) \\
Agrofostry site & Sycamore (Acer pseudoplatanus) & - \\
\hline
\end{tabular}

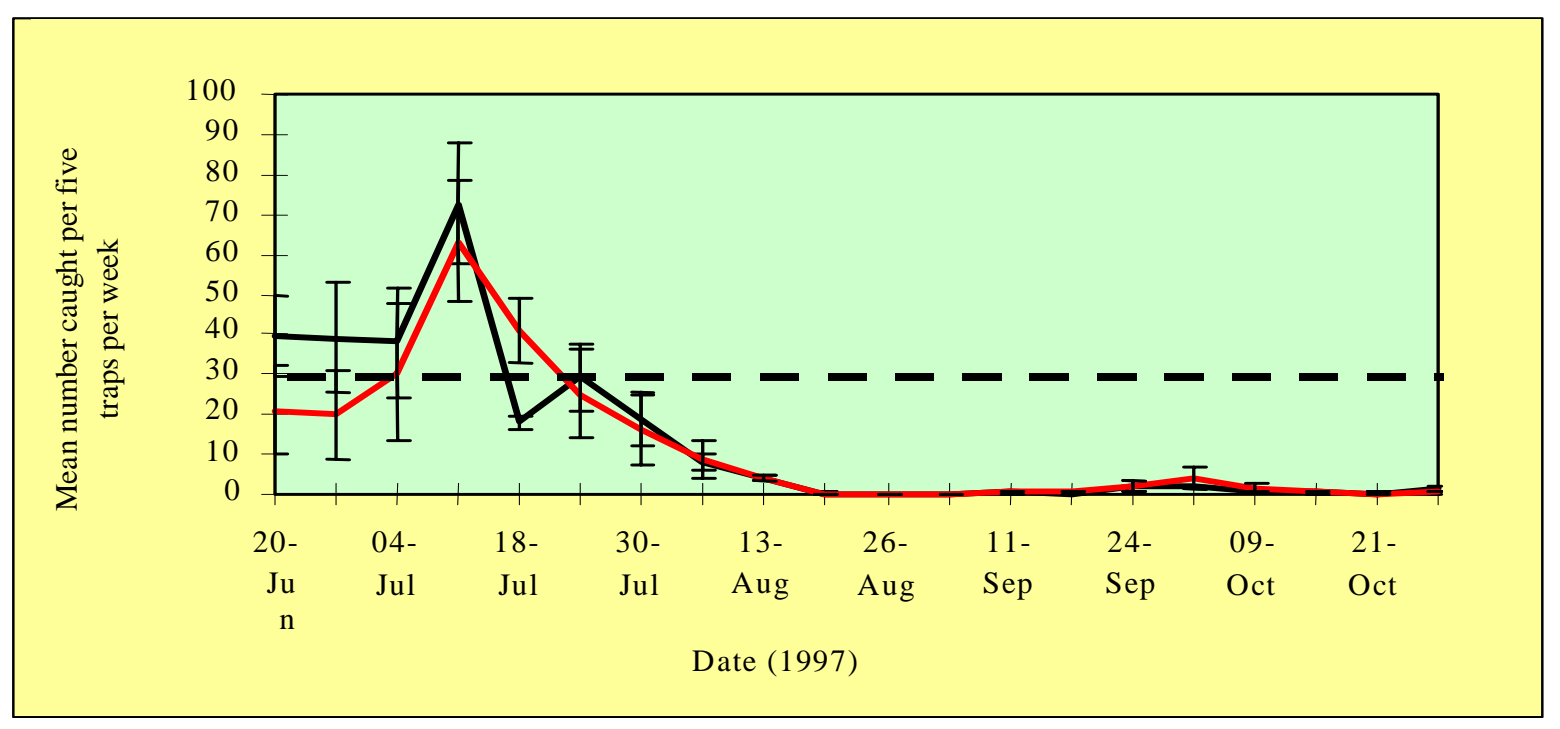

Figure 1: Mean number of Archips podana captured in pheromone traps in five managed orchards $(-)$ and five unmanaged habitats ( $(-)$. Recommended spray threshold (------). Bars are \pm standard errors of the mean 
The ADAS action threshold (30 moths per trap per week) was well exceeded. A small second generation of moths was noted during mid-September to early October. No A. podana were captured in the light trap or by spotlight sweep netting in the orchards.

\section{Discussion and Conclusion}

The capture of moths within attractant traps will depend on both distance of attraction and possible interaction between neighbouring traps along with other factors such as prevailing wind direction (van der Kraan and van Deventer, 1982). Firm information on these distances is unavailable, although more is known about capturing than interfering distances. Minks and Noordink (1971) captured male Adoxophyes orana up to a distance of $75 \mathrm{~m}$. Wall and Perry (1980) found an attraction distance of $100 \mathrm{~m}$. for Cydia nigricana (pea moth). No attraction distance for the pheromone used for A. podana attraction has been published.

As the light trap or spotlight sweep netting failed to capture any A. podana in the orchards would support the hypothesis that moths were pulled-in from surrounding habitats. Archips podana are polyphagous and feed on many tree species (Carter, 1984). However, with no significant difference occurring between managed orchards and unmanaged surrounding habitats, the results suggest that the moths are occurring in the area but are not concentrated in any particular habitat.

No significant damage was caused to fruit of the apple trees by $A$. podana throughout the study ( $<1 \%$ was designated as insect damage, Department of Agriculture and Rural Development for Northern Ireland, unpublished data), despite their numbers greatly exceeding the ADAS action threshold.

Nonetheless, with populations well above the ADAS threshold, damage would be expected. Reasons for this are unclear but it may be due to a feeding preference by the larvae: the Bramley fruit may simply be too acidic for the larvae to feed upon. In New Zealand apple orchards the predatory mite Anystis baccarum (Linnaeus) has been cited as a valuable predator of tortricid larvae (Baker, 1983). Anystis baccarum is common within commercial Northern Irish Bramley orchards (Cuthbertson, 2004, 2005; Cuthbertson and Murchie, 2004a and b and Cuthbertson and Murchie, 2005a and b) and has been shown to readily feed upon other economically important invertebrate pest species occurring in the orchards (Cuthbertson and Murchie, 2003;
Cuthbertson, et al., 2003a and b; Cuthbertson and Murchie, 2004b). It will no doubt also prey on $A$. podana larvae.

The current ADAS action threshold for A. podana has not been specifically designed for Bramley's Seedling apple orchards but for dessert apple orchards (Cross and Berrie, 1994), therefore, the need to spray must be carefully calculated. Apple growers must move away from the 'calendar spraying' regime that currently operates within many UK apple orchards. The benefits of such a move would be huge in terms of both economic and environmental aspects. The capture of moths by the pheromone traps does not prove that the moths are resident in the orchard, or that their larvae use apple as a host. Pheromone-trap catches only indicate relative activity for the particular species captured (Cross, 1996). The findings from this study would indicate that $A$. podana are commonly occurring in many habitats including the apple orchards. However, they are not concentrated in any particular habitat. Therefore, considerable judgement by the individual apple grower, weighing up the potential of moth larvae damage with the economics of chemical control and the effects on the environment needs to be undertaken before deciding to apply pesticides to control A. podana. Thus, helping to avoid unnecessary pesticide applications and move the Northern Irish apple industry towards a more long term environmentally sustainable production system.

Archips podana are widely occurring in all habitats and are not concentrated within the Bramley apple orchards. Their numbers regularly occur above the recommended ADAS spray threshold, however, economic damage is rarely recorded. There is a need for fruit growers to weight up the potential risk of fruit damage against the effect of unnesessary pesticide applications on the environment and nontarget species before deciding to apply chemicals against $A$. podana.

\section{Acknowledgement}

Dr. Andrew G. S. Cuthbertson was funded by a Department of Agriculture and Rural Development (Northern Ireland) studentship.

\section{References}

Alford, D. V., A Colour Atlas of Fruit Pests, Their Recognition, Biology and Control. Wolfe Publishing Ltd. London,: 320, 1984

Baker, R. T., Predation of leafroller larvae by spiders and mites. Weta., 6: 22-23, 1983 
Bradley, J. D., Tremewan, W. G. and A. Smith, British Tortricoid Moths. Cochylidae and Tortricoidae: Tortricinae. The Ray Society, London, 1: 102-103, 1973

Carter, D. J., Pest Lepidoptera of Europe. Kluwer Academic Publishers, Lancaster: 431, 1984

Cross, J. V., A pheromone trap survey of tortricid moths (Lepidoptera:Tortricidae) in apple orchards in England subject to different insecticide management. Entomologist, 115: 168-180, 1996

Cross, J. V. and A. M. Berrie, Sampling and assessment of pests and diseases as the basis for decision making in orchards in the UK. Asp. Appl. Bio., 37: 225-236, 1994

Cuthbertson, A. G. S., Unnecessary pesticide applications in Northern Ireland apple orchards due to misidentification of a beneficial mite species. Res. J. Chem. Environ., 8 (3): 77-78, 2004

Cuthbertson, A. G. S., Re-discovery of a predatory mite in Northern Irish apple orchards. Bio. News, 30 (1): 29, 2005

Cuthbertson, A. G. S. and A. K. Murchie, The impact of fungicides to control apple scab (Venturia inaequalis) on the predatory mite Anystis baccarum and its prey Aculus schlechtendali (apple rust mite) in Northern Ireland Bramley orchards. Crop Prot., 22: 1125-1130, 2003

Cuthbertson, A. G. S. and A. K. Murchie, The presence of Anystis baccarum (L.) in Northern Ireland Bramley apple orchards. Irish Naturalists' Journal, 27: 465467, 2004a

Cuthbertson, A. G. S. and A. K. Murchie, The phenology, oviposition and feeding rate of Anystis baccarum, a predatory mite in Bramley apple orchards in Northern Ireland. Exp. Appl. Acarol., 34: 367-373, $2004 b$

Cuthbertson, A. G. S. and A. K. Murchie, Techniques for environmental monitoring of predatory fauna on branches of Bramley apple trees in Northern Ireland. Int. J. Environ. Sci. Tech., 2 (1): 1-6, $2005 a$

Cuthbertson, A. G. S. and A. K. Murchie, Little-known mite gives new hope in Ireland. The Fruit Grower, 3: $6,2005 b$
Cuthbertson, A. G. S., Bell, A. C. and A. K. Murchie, Impact of the predatory mite Anystis baccarum (Prostigmata: Anystidae) on apple rust mite Aculus schlechtendali (Prostigmata: Eriophyidae) populations in Northern Ireland Bramley orchards. Ann. Appl. Bio., 142: 107-114, $2003 a$

Cuthbertson, A. G. S., Fleming, C. C. and A. K. Murchie, Detection of Rhopalosiphum insertum (apple-grass aphid) predation by the predatory mite Anystis baccarum using molecular gut analysis. Agricultural and Forest Entomology, 5: 219-225, 2003b

Massee, A. M., The Pests of Fruit and Hops (2 ${ }^{\text {th. }}$ Ed.). Crosby Lockwood and Son Ltd. London,: 284, 1946

Massee, A. M., The Pests of Fruits and Hops ( $3^{\text {th. }}$ Ed.). Crosby Lockwood and Son Ltd. London,: 338, 1954

Mowat, D. J. and S. Clawson, The need for pest control in Northern Ireland Bramley apple orchards. Crop Protection in Northern Britain, 2: 225-230, 1996

Mészáros, Z., L. Ádám, K. Balázs, I. M. Benedek, , C. Csikai, A. D. Draskovits, F. Kozár, G. Lövei, S. Mahunka, A. Meszleny, F. Mihályi, K. Mihályi, L. Nagy, B. Oláh, J. Papp, L. Papp, L. Polgár, Z. Radwan, V. Racz, L. Ronkay, P. Solymosi, A. Soós, S. Szabó, C. Szabóky, L. Szalay-Marzsó, I. Szarukán, G. Szelényi, F. Szentkirályi, G. Sziráki, L. Szöke and J. Török, Results of faunistical and floristical studies in Hungarian apple Orchards (Apple Ecosystem Research No. 26). Acta Phytopath. Hun., 19: 91-96, 1984

Minks, A. K. and J. Ph.W. Noordink, Sex attraction of the summerfruit tortrix moth, Adoxophyes orana: Evaluation in the field. Entomol. Exp. Appl., 14: 5772, 1971

van der Kraan, C. and P. van Deventer, Range of action and interaction of pheromone traps for the summerfruit tortrix moth, Adoxophyes orana (F.v.R). J.Chem. Ecol., 8: 1251-1262, 1982

Wall, C. and J. N. Perry, Effects of spacing and trap number on interactions for the pea moth, Cydia nigricana (F). Entomol. Exp. Appl., 28: 313-321, 1980 